\title{
Increased islet beta cell replication adjacent to intrapancreatic gastrinomas in humans
}

\author{
J. J. Meier • A. E. Butler • R. Galasso • R. A. Rizza • \\ P. C. Butler
}

Received: 14 June 2006 / Accepted: 24 July 2006 / Published online: 23 September 2006

(C) Springer-Verlag 2006

\begin{abstract}
Aims/hypothesis Type 1 and type 2 diabetes are characterised by a beta cell deficit. Islet hyperplasia has been described in patients with Zollinger-Ellison syndrome secondary to gastrin-producing tumours (gastrinomas), and gastrin therapy has increased beta cell mass in rodents and human islets in vitro. In the present studies we addressed the following questions: (1) In pancreas specimens from gastrinoma cases, is the fractional beta cell area increased? (2) If so, is this restricted to tumour-adjacent islets or also present in tumour-distant islets? (3) Is new beta cell formation (beta cell replication and islet neogenesis) increased and beta cell apoptosis decreased in pancreas specimens from gastrinoma cases?

Methods Pancreas was obtained at surgery from four patients with Zollinger-Ellison syndrome caused by pancreatic gastrinomas and 15 control subjects at autopsy.

Results Islet fractional beta cell area $(p<0.001)$, islet size $(p<0.001)$ and beta cell replication (Ki67 staining) $(p<0.05)$ were increased in islets adjacent to the tumours, but not in tumour-distant pancreas, compared with control subjects. We did not observe any differences in beta cell apoptosis or in the number of insulin-positive cells in ducts either adjacent to or distant from the tumour.
\end{abstract}

J. J. Meier · A. E. Butler $\cdot$ R. Galasso $\cdot$ P. C. Butler $(\bowtie)$

Larry Hillblom Islet Research Center,

UCLA David Geffen School of Medicine,

24-130 Warren Hall, 900 Veteran Avenue,

Los Angeles, CA 90095-7073, USA

e-mail: pbutler@mednet.ucla.edu

R. A. Rizza

Division of Endocrinology, Diabetes, Metabolism and Nutrition,

Mayo Clinic,

Rochester, MN, USA
Conclusions/interpretation One or more factors released by human gastrinomas increase beta cell replication in islets immediately adjacent to the tumour, but not in tumourdistant islets. While these findings demonstrate that adult human beta cells can be driven into the cell cycle, they caution against the therapeutic usefulness of gastrin, since islets located $>1 \mathrm{~cm}$ away from the gastrinomas did not exhibit changes in beta cell turnover, despite markedly elevated systemic gastrin levels sufficient to cause severe gastrointestinal symptoms.

Keywords Beta cell mass - Beta cell replication .

Gastrinoma $\cdot$ Islet hyperplasia $\cdot$ Zollinger-Ellison syndrome

\author{
Abbreviations \\ DAPI 4,6-diamidino-2-phenylindole \\ MEN1 multiple endocrine neoplasia type 1 \\ TUNEL terminal deoxynucleotidyl transferase-mediated \\ dUTP-biotin nick end-labelling
}

\section{Introduction}

Type 1 and type 2 diabetes are characterised by impaired insulin secretion and diminished beta cell mass [1-3]. Beta cell replacement therefore represents a possible therapeutic approach for patients with diabetes [4]. Pancreas and islet transplantation restore insulin secretion and glucose control in patients with type 1 and type 2 diabetes $[5,6]$. However, donor shortage, the need for life-long immunosuppression, and progressive graft failure in islet transplantation limit these treatments $[7,8]$. An alternative approach to increase beta cell mass in patients with diabetes would be to enhance beta cell 
regeneration from endogenous sources and/or to inhibit beta cell apoptosis $[4,9,10]$.

The gastrointestinal hormone gastrin increased beta cell mass and alleviated hyperglycaemia in rodent models of diabetes [11-13]. However, the capacity for beta cell regeneration appears to be less in humans than in rodents $[2,14-16]$, and the effect of chronic hypergastrinaemia on beta cell mass and replication in humans is unknown. Moreover, chronic administration of gastrin to patients is associated with a high frequency of gastrointestinal side effects [17], thus limiting clinical studies in humans where the effects on beta cell mass would not be measurable.

One way of studying the potential effects of gastrin on beta cell replication in humans in vivo is to examine the pancreas removed surgically from patients with gastrinproducing tumours. Indeed, excessive secretion of gastrin resulting in the induction of gastrointestinal ulcers and diarrhoea is a typical feature of patients with ZollingerEllison syndrome [17, 18], and previous studies reported increased islet size in pancreatic specimens from patients with gastrinomas [18-20]. Pancreatic endocrine tumours may release many growth factors [21]; thus, the apparent increase in islet size might have been due to paracrine release of tumour-related factors rather than systemic gastrin. In the case of the former, the islet hyperplasia might be expected to be more prominent in islets adjacent to the tumour. Also, it is not known through which mechanism islet hyperplasia occurs in gastrinoma cases, and changes in beta cell turnover (new beta cell formation and beta cell apoptosis) have not yet been studied in such patients.

In the present studies, we addressed the following questions: (1) Is the fractional beta cell area increased in patients with intrapancreatic gastrinomas? (2) If so, is this effect restricted to islets adjacent to the tumour (suggesting a paracrine effect) or also present in more tumour-distant islets (suggesting a systemic effect)? (3) Is new beta cell formation (beta cell replication and putative islet neogenesis from ductal cells) increased and is beta cell apoptosis decreased in pancreas specimens from gastrinoma cases?

\section{Subjects and methods}

Study protocol The study protocol was approved by the Institutional Review Board of the Mayo Clinic (Rochester, MN, USA) (IRB-no. 180-05).

Cases Human pancreatic tissue was obtained at surgery from four patients (one female, three male), who underwent laparotomy for the removal of pancreatic gastrinomas. All patients presented with typical Zollinger-Ellison syndrome (diarrhoea, nausea, gastrointestinal ulcers). This clinical diagnosis was confirmed in all cases by highly elevated plasma levels of gastrin (Table 1), as well as by the detection of pancreatic tumours. The symptoms of ZollingerEllison syndrome and the high gastrin levels resolved in each of the four cases after resection of the pancreatic tumour.

The patients were $51.0 \pm 5.5$ [means \pm SD] years old, and presented with a BMI of $25.4 \pm 1.8 \mathrm{~kg} / \mathrm{m}^{2}$. All cases were non-diabetic prior to surgery. One case (no. 1) presented with multiple endocrine neoplasia type 1 (MEN1). The other three cases presented with a single intrapancreatic gastrinoma. A clinical diagnosis of MEN was excluded in these cases by the absence of hypoglycaemia, hyperparathyroidism and additional intrapancreatic or pituitary adenomas at diagnosis or during follow-up. The number of tissue blocks analysed in each case was 14, 10, 4 and 3, respectively. Sections of tumour tissue and of tumour-free pancreas tissue were available from all cases.

Control subjects Human pancreatic tissue from 15 nondiabetic subjects (seven male, eight female) of similar age and BMI and without a history of Zollinger-Ellison syndrome or other endocrine diseases was obtained at autopsy. They were $52.8 \pm 8.4$ years old ( $p=0.69$ vs gastrinoma cases), with a BMI of $25.3 \pm 1.8 \mathrm{~kg} / \mathrm{m}^{2}$ ( $\left.p=0.92\right)$. To be included, control subjects were required to have (1) had a full autopsy within $24 \mathrm{~h}$ of death, and (2) pancreatic tissue stored that was of adequate size and quality. Subjects were excluded if pancreatic tissue had undergone autolysis or showed evidence of acute pancreatitis.

Pancreatic tissue processing Pancreas was fixed in formaldehyde and embedded in paraffin for subsequent analysis as previously described [2]. Sequential 5- $\mu \mathrm{m}$ sections were stained as follows: (1) for insulin (peroxidase staining) and haematoxylin for light microscopy; (2) gastrin (peroxidase staining) and haematoxylin for light microscopy; (3) insulin, terminal deoxynucleotidyl transferase-mediated dUTPbiotin nick end-labelling (TUNEL) and 4,6-diamidino-2-

Table 1 Characteristics of the four patients with intrapancreatic gastrinomas

\begin{tabular}{|c|c|c|c|c|c|}
\hline $\begin{array}{l}\text { Case } \\
\text { no. }\end{array}$ & $\begin{array}{l}\text { Age } \\
\text { (years) }\end{array}$ & $\begin{array}{l}\text { BMI } \\
\left(\mathrm{kg} / \mathrm{m}^{2}\right)\end{array}$ & $\begin{array}{l}\text { Pre-operative } \\
\text { gastrin levels } \\
(\mathrm{pg} / \mathrm{ml})\end{array}$ & $\begin{array}{l}\text { Intrapancreatic } \\
\text { tumour localisation }\end{array}$ & $\begin{array}{l}\text { Tumour } \\
\text { dignity }\end{array}$ \\
\hline 1 & 45 & 26.8 & 300 & Head, tail & Benign \\
\hline 2 & 54 & 23.1 & 980 & $\begin{array}{l}\text { Head, uncinate } \\
\text { process }\end{array}$ & Malignant \\
\hline 3 & 57 & 26.8 & 370 & Body, tail & Malignant \\
\hline 4 & 48 & 25.1 & 3000 & Body & Malignant \\
\hline
\end{tabular}


phenylindole (DAPI) combined (immunofluorescence); and (4) insulin, Ki67 and DAPI combined (immunofluorescence).

For immunohistochemistry the following primary antibodies were used: guinea pig anti-insulin (1:400, Lot-no. 50381573; Dako, Grostrup, Denmark); mouse Ki67 (1:200, MIB-1, Lot-no. 00014101; Dako), rabbit anti-gastrin (Lot-no. 402203; Novocastra, Newcastle upon Tyne, UK). Secondary antibodies labelled with Cy3, FITC and AMCA were obtained from Jackson Laboratories (West Grove, PA, USA) and used at dilutions of 1:100 to 1:200. For TUNEL staining, an in situ cell death detection kit, TMR Red from Roche Diagnostics (Indianapolis, IN, USA) was used.

Morphometric analysis For morphometric analyses, pancreatic tissue in all cases was divided into (1) tumour tissue, (2) pancreatic tissue directly adjacent to the tumour (within $1 \mathrm{~cm}$ ) and (3) pancreatic tissue not adjacent to the tumour (distance $>1 \mathrm{~cm}$ ). For the determination of the fractional beta cell area, each pancreatic section was imaged at $\times 40$ magnification ( $\times 4$ objective), and the ratio of the beta cell area:exocrine area was digitally quantified, as previously described [2], using Image Pro Plus software, version 4. 5.1 (Media Cybernetics, Silver Springs, MD, USA).

For the determination of beta cell replication and beta cell apoptosis, the number of beta cells positive for Ki67 or TUNEL was manually counted in each tissue section and expressed in relation to the respective beta cell area.

For the determination of islet size, 20 representative islets adjacent to the tumour (within $1 \mathrm{~cm}$ ) and distant from the tumour $(>1 \mathrm{~cm}$ from the tumour) were imaged in the gastrinoma cases, and 15 representative islets were imaged in the control subjects, all at $\times 20$ magnification. Each islet was then analysed using Image Pro Plus software, as previously described [2].

To measure the nuclear diameter, insulin-stained sections of pancreas (peroxidase) counterstained with haematoxylin were used, as previously described [22]. Five islets per section selected at random were photographed at $\times 200$ magnification on an Olympus IX70 inverted system microscope (Olympus America, Melville, NY, USA). These islets were then examined to identify five representative beta cell nuclei each. Selection criteria included the clear presence of the nucleus within a beta cell, the ability to clearly visualise nuclear boundaries, circular shape (similar dimensions in all directions), and the appearance to the observer that the nucleus had been sectioned through its maximum diameter. Once the identified nucleus was encircled, measurement of 180 nuclear diameters per nucleus was made using Image Pro Plus software, which quantified these 180 diameters at $2^{\circ}$ angles throughout the circumference of the nucleus. Thus, the mean of 4500 single measurements per subject was used to compute the mean nuclear diameter per section. To evaluate the association of beta cells with exocrine ducts, the percentage of duct cells that were immunoreactive for insulin was quantified in each section, as previously described [2].

Statistical analysis Subject characteristics are reported as means \pm SD, results are presented as means \pm SEM. Statistical calculations were carried out by one-way ANOVA and Duncan's post hoc test or the Student's $t$-test, as appropriate, using Statistica, version 6.0 (Statsoft, Tulsa, OK, USA). A $p$ value of $<0.05$ was taken to indicate a significant difference.

\section{Results}

Pre-operative plasma gastrin levels were elevated in all cases with Zollinger-Ellison syndrome (1,162 $\pm 631 \mathrm{pg} / \mathrm{ml}$; normal range $0-115 \mathrm{pg} / \mathrm{ml}$; Table 1$)$. Tumour tissue was identified in the pancreatic sections from all cases. Gastrin staining was detectable in tumour specimens from two out of four cases, at variable intensities. Insulin-positive cells were also occasionally observed in tumour specimens from all cases (Fig. 1).

Histological evaluation of the tumour-free pancreatic tissue demonstrated hyperplastic islets in all cases with Zollinger-Ellison syndrome compared with healthy control subjects, but these were located in close proximity to the tumour, and islets more remote from the tumours did not appear to be enlarged. Islets adjacent to the tumours were often found embedded in connective tissue as well as in close proximity to adipocytes (Fig. 2), but islet hyperplasia was also readily detectable in tumour-adjacent islets that were surrounded by exocrine acinar parenchyma.

The fractional beta cell area was greater in the tumour-free pancreas of the gastrinoma cases than in the pancreas of the control subjects (Fig. 3). However, on further analysis it was apparent that this increase in the fractional beta cell area was only present within a 1-cm margin of the tumour; the fractional beta cell area was not increased in the tumour-distant pancreas $(p<0.001$; Fig. 3). The increase in fractional beta cell area in the tumour-adjacent pancreas tissue from cases with Zollinger-Ellison syndrome was accounted for by an increase in islet size $(p<0.001$; Fig. 3$)$.

Beta cell replication, as measured by the frequency of Ki67 labelling, was increased in the tumour-adjacent pancreas tissue from the gastrinoma cases $(p<0.05$; Figs. 4 and 5). In contrast, there was no detectable difference in beta cell replication between the tumour- 
Fig. 1 Pancreatic tumour removed from a patient with Zollinger-Ellison syndrome (case no. 2). Adjacent sections were stained for gastrin (a) and insulin (b) and imaged at $\times 40$ magnification. Inserts show parts of the same sections at $\times 200$ magnification

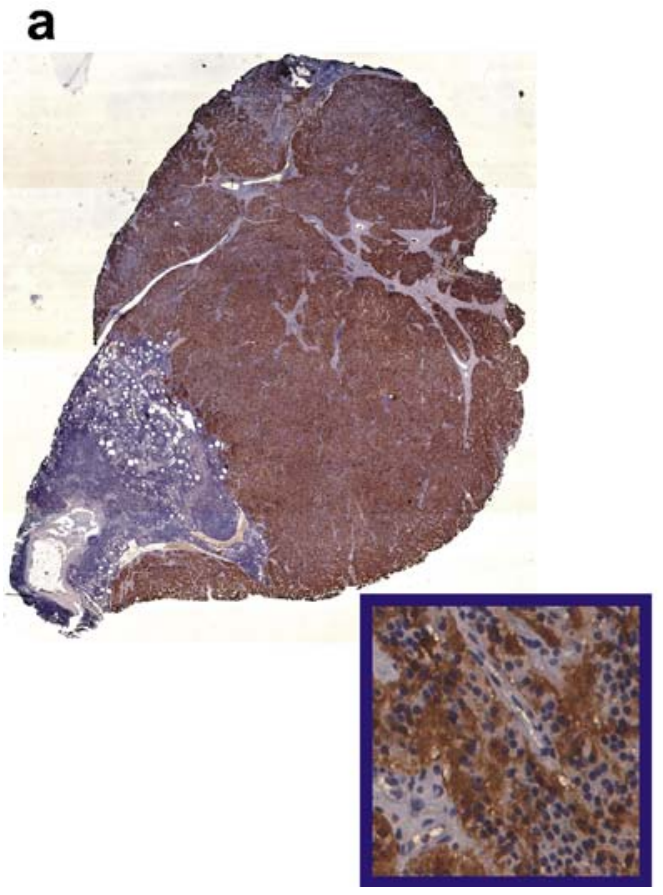

b

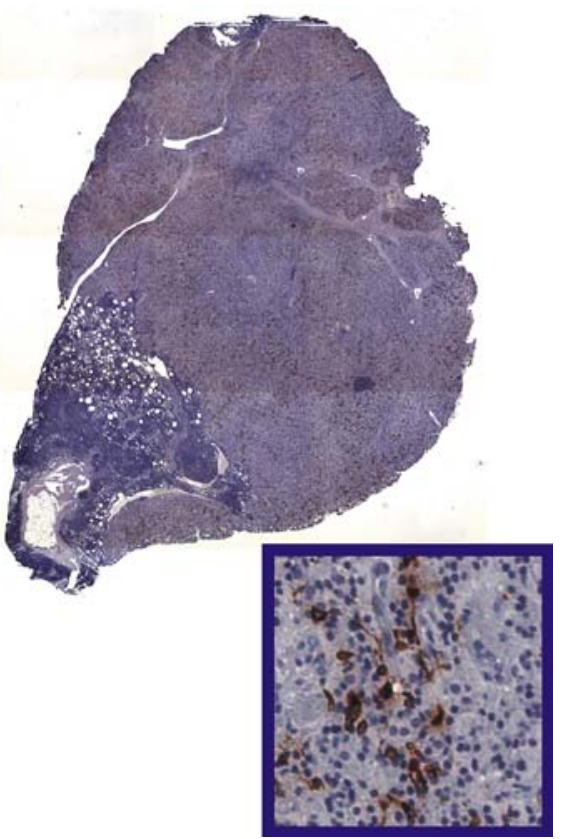

distant pancreatic tissue from the cases and the control tissue (Fig. 5). The percentage of duct cells positive for insulin was not different between gastrinoma cases and control subjects $(p=0.68)$, either adjacent to or remote from the tumour.

The mean beta cell nuclear diameter was decreased in gastrinoma cases relative to that in control subjects $(p<0.001$; Fig. 6). There was no difference in the beta cell nuclear size between the tumour-adjacent and the tumour-distant tissue specimens from the gastrinoma cases $(p=0.49)$.

\section{Discussion}

We report that, in gastrinoma cases, the fractional beta cell area and the mean islet size are increased in tumour-adjacent pancreas but not in pancreas $>1 \mathrm{~cm}$ from the tumour. Moreover, we report increased beta cell replication in islets adjacent to gastrinomas, but not in tumour-distant islets.

The present findings are consistent with previous reports showing islet hyperplasia in pancreas specimens from some patients with Zollinger-Ellison syndrome [18-20]. In the earlier studies, one might have argued that the coincidence of islet hyperplasia and gastrinoma may have indicated underlying MEN1. However, here we note that the islet hyperplasia is restricted to the rim of pancreas around the gastrinoma, and does not involve islets $>1 \mathrm{~cm}$ from the tumour, implying that a product of the tumour rather than neoplastic transformation is driving beta cell hyperplasia. Therefore, our studies extend the prior findings to show that fractional beta cell area is increased as a result of upregulated beta cell replication and that both islet hyperplasia and increased beta cell replication are restricted to islets adjacent to the pancreatic tumours. Since the circulating plasma levels of gastrin were markedly elevated in all patients with Zollinger-Ellison syndrome, this suggests that promotion of beta cell replication in humans in vivo either requires the very high concentrations of gastrin released immediately adjacent to the tumour or, indeed, may be a consequence of local release of other secretory products from these pancreatic tumours.

The islet hyperplasia in the case with MEN type 1 reported could theoretically be a consequence of beta cell neoplasia. However, the fact that islet hyperplasia in this case was also restricted to the tumour-adjacent areas, comparable to the results of the other three cases examined and inconsistent with any pattern reported in MEN 1 previously, argues against this possibility.

In addition to gastrin and insulin, a broad variety of other growth factors, such as TGF- $\alpha$ and $-\beta$, IGF-1, platelet-derived growth factor (PDGF), fibroblast growth factor (FGF), vascular endothelial growth factor (VEGF), and ErbB-3 are abundantly expressed by endocrine pancreatic tumours [21]. Many of these factors are well known to stimulate beta cell growth in vitro [11, 23-28]. Further support for a possible gastrin-independent mechanism for the increased beta 

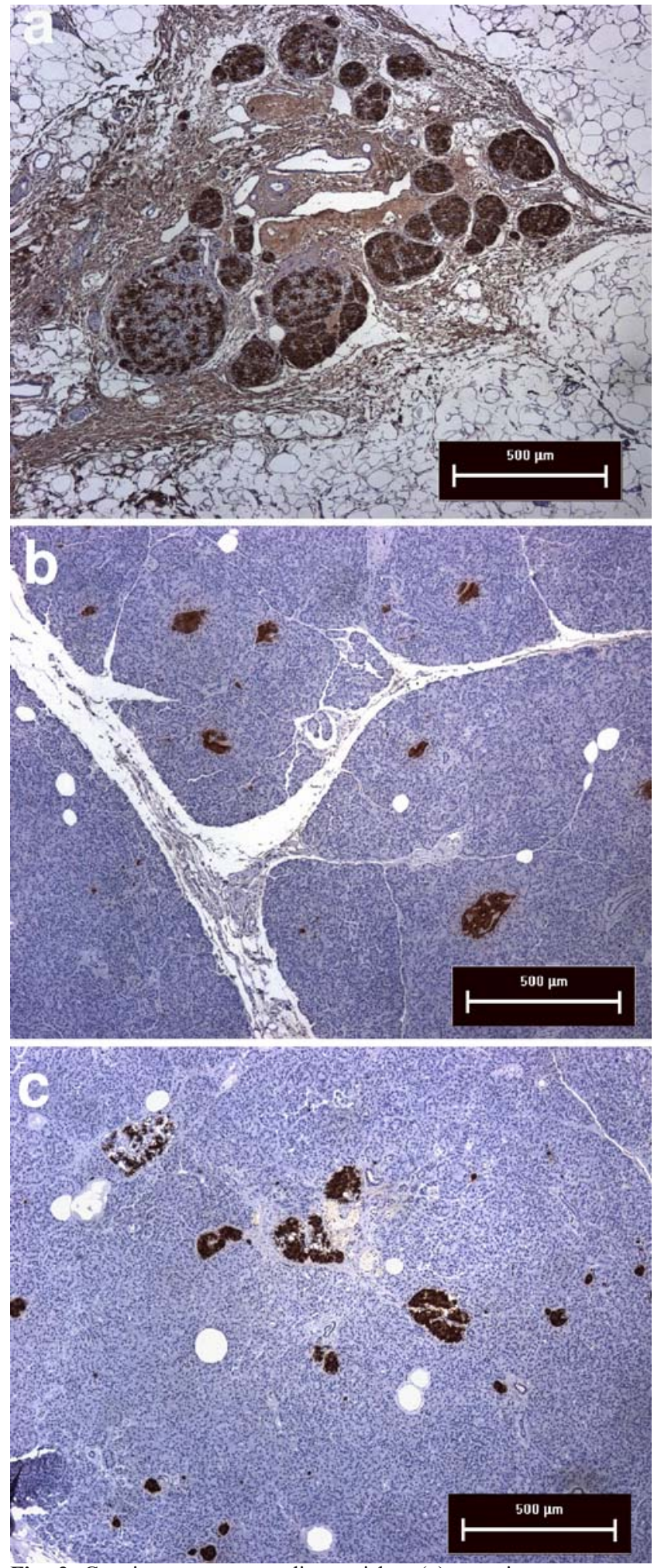

Fig. 2 Gastrinoma, tumour-adjacent islets (a); gastrinoma, tumourdistant islets (b); and control pancreas islets (c). There is marked islet hyperplasia in tumour-adjacent tissue
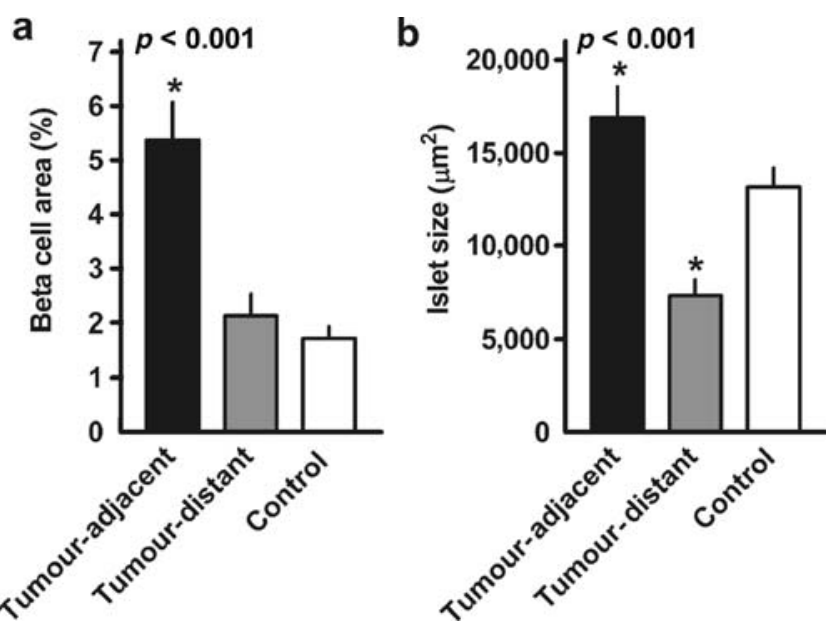

Fig. 3 Fractional beta cell area (a) and islet size (b) in tumouradjacent and tumour-distant pancreatic sections from patients with Zollinger-Ellison syndrome and control subjects. Data are presented as means \pm SEM; statistics were carried out by one-way ANOVA; *significant differences vs control (Duncan's post hoc test)

cell replication adjacent to gastrinomas is the increased beta cell proliferation in the absence of gastrin staining and despite the low gastrin content in tumour lysates observed in the present as well as in previous studies $[19,29]$. Moreover, the expansion of beta cell mass previously shown in rodent studies was much more pronounced during the combined administration of EGF and gastrin than with gastrin alone [11, 12].

The sources of new beta cells in adult humans remain to be fully elucidated $[4,10,30]$. Lineage tracing studies suggest that replication of pre-existing beta cells is the primary mechanism for postnatal growth and regeneration of beta cells in mice [31]. Other sources of beta cells have been proposed, including progenitor cells residing in exocrine ducts $[2,15]$, bone marrow stem cells [32], and de-differentiation of beta cells to replicating epithelial cells prior to re-differentiation [33]. It is not possible to quantify with certainty any of these potential alternative sources of beta cells in human studies. The percentage of ductal cells positive for insulin is a proposed indirect measure of so-called ductal islet neogenesis [2, 34]. There was no increase in this index in the present gastrinoma cases.

In contrast, the frequency of beta cell replication was markedly increased in tumour-adjacent pancreas specimens. These findings therefore suggest that the replication of existing beta cells did at least in part mediate beta cell hyperplasia in islets adjacent to the tumours, even though other sources of new beta cells cannot be ruled out. Of note, studies in non-obese diabetic mice treated with EGF and gastrin also revealed large islets, suggesting that increased replication of beta cells 
Fig. 4 Sections of tumour-adjacent pancreatic tissue in two patients with Zollinger-Ellison syndrome (cases no. 3 (a) and 4 (b)) stained for insulin (green), Ki67 (red) and DAPI. Images were taken at $\times 200$ magnification
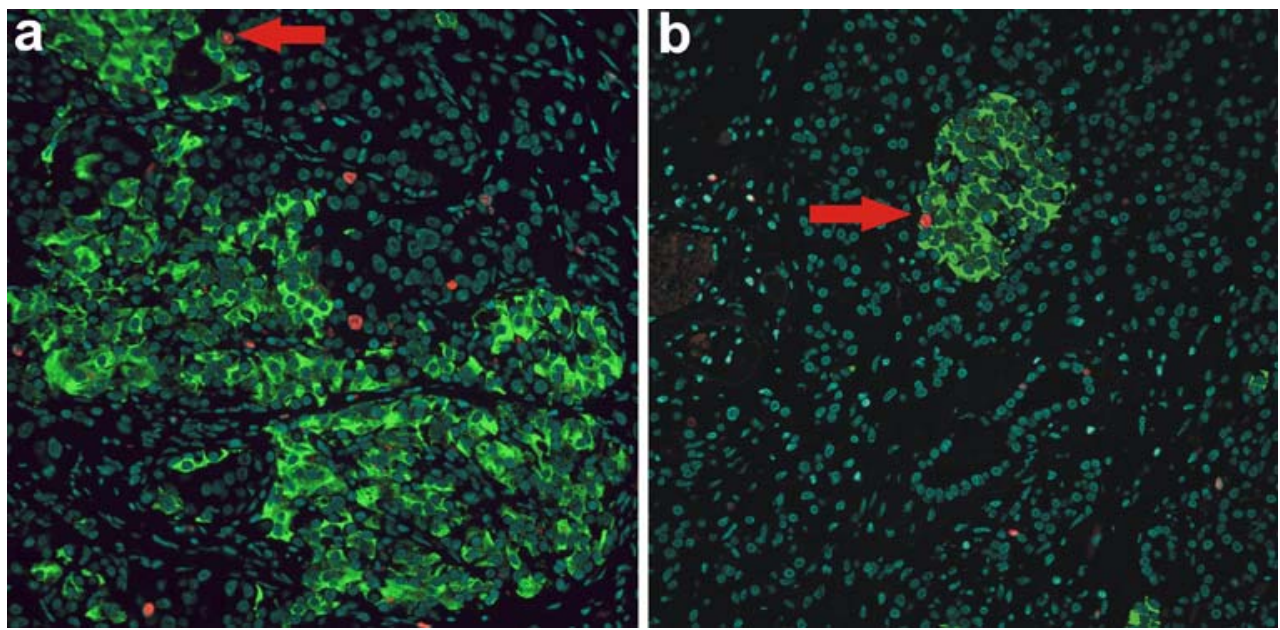

within existing islets was a mechanism contributing to the observed increase in beta cell mass [12]. While beta cell replication is rare in adult humans, including those with long-standing type 2 diabetes [2,9], we have recently reported increased beta cell replication countered by high rates of beta cell apoptosis in an 89-year-old patient with recent-onset type 1 diabetes [35]. Taken together, these reports reveal that beta cells in adult humans do retain the capacity for replication.

An interesting finding from the present studies was the decreased beta cell nuclear diameter in gastrinoma cases compared with control subjects. We recently reported that the beta cell nuclear diameter correlates closely with the BMI in humans [22]. One possible explanation for this is that the nuclear diameter in human beta cells is related to proinsulin synthesis, i.e. insulin demand per beta cell. Although this currently remains unproven for beta cells, it is consistent with findings in other endocrine cells, such as parathyroid cells, in humans [36, 37]. In the present study, the lower beta cell nuclear diameter in gastrinoma cases would be consistent with a compensatory downregulation of insulin secretion per beta cell in response to increased beta cell mass, and may explain the absence of hypoglycaemia despite an increase in beta cell mass in patients with gastrinomas.

The induction of beta cell regeneration from endogenous sources has been suggested as a promising future target for the treatment of patients with diabetes $[4,9]$, and a number of compounds have been proposed to enhance the formation of new beta cells. Specifically, the gastrointestinal hormones gastrin, glucagon-like peptide 1 (GLP-1) and gastric inhibitory polypeptide (GIP) have been shown to induce beta cell proliferation in different in vitro models $[11,38-40]$. However, it is difficult to directly translate these findings to the in vivo situation in adult humans, because the peptide concentrations used in those experiments were often far above the tolerable plasma concentrations in humans, and because the mitotic capacity of beta cells in culture is much higher than that of beta cells under in vivo conditions [41, 42]. In the present studies,
Fig. 5 Frequency of beta cell replication (a), percentage of duct cells positive for insulin (b), and frequency of beta cell apoptosis (c) in tumour-adjacent and tumour-distant pancreatic sections from patients with Zollinger-Ellison syndrome and control subjects. Data are presented as means \pm SEM. Statistics were carried out by one-way ANOVA; $p$ values are shown on the graphs. *Significant differences vs control (Duncan's post hoc test)

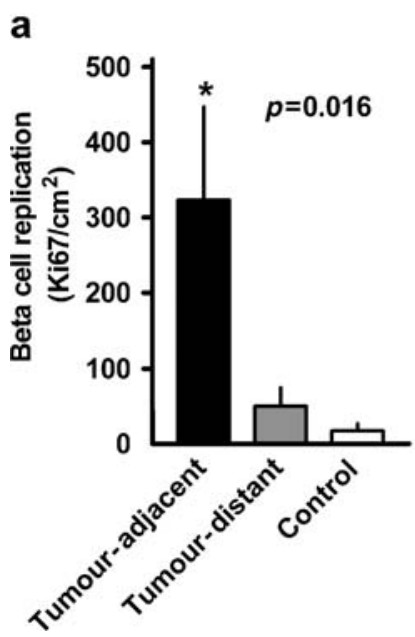

b

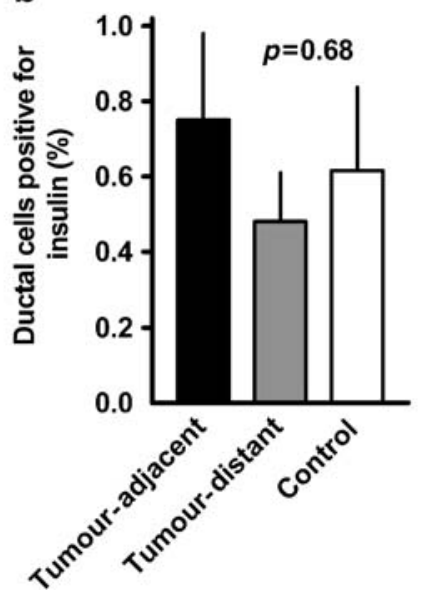

C

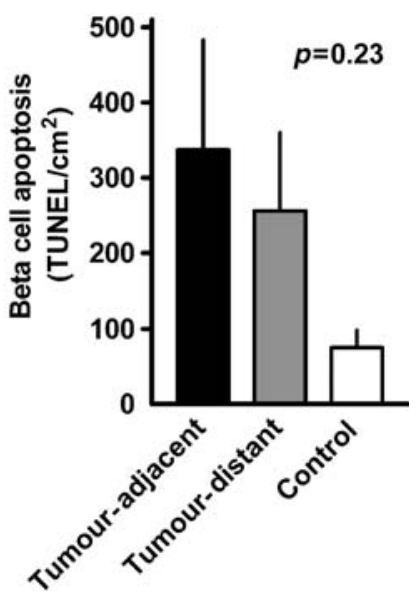


Fig. 6 Mean nuclear diameter of beta cells in tumour-adjacent and tumour-distant pancreatic sections from patients with Zollinger-Ellison syndrome and control subjects. Data are presented as means \pm SEM. Statistics were carried out by one-way ANOVA; $p$ value is shown on the graph. *Significant differences vs control (Duncan's post hoc test)

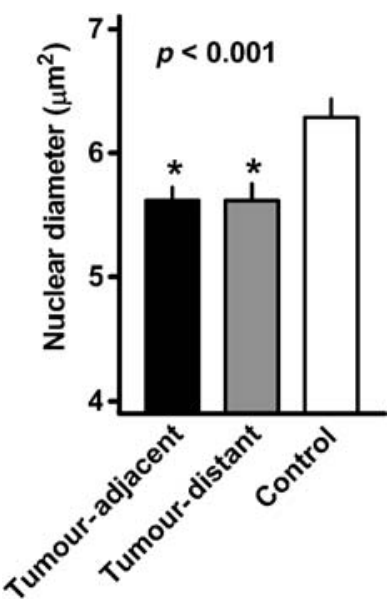

relative beta cell area and beta cell proliferation were normal in pancreas specimens that were not adjacent to the tumours, despite the presence of plasma concentrations of gastrin sufficient to lead to Zollinger-Ellison syndrome [17]. These results suggest that gastrin is not a suitable therapeutic approach for enhancement of new beta cell formation for diabetes therapy. Moreover, as discussed above, it is quite possible that the increased beta cell replication observed in gastrinomas is not driven by gastrin. Also, any effort to drive beta cell replication as an approach to restore beta cell mass in type 1 or type 2 diabetes is likely to be unsuccessful unless the underlying cause of the increased beta cell apoptosis is addressed, since replicating cells have an increased vulnerability to apoptosis [43, 44].

Like all studies, the present studies have limitations. The four cases of pancreatic gastrinoma are relatively few, but it will be appreciated that this is a very rare disease [19]. We have compared pancreas from the four cases of gastrinoma with pancreas obtained at autopsy, albeit autopsies performed relatively rapidly after death and with well-preserved tissue. Nonetheless, it is possible that differences between gastrinoma cases and control subjects might be influenced by this different source of pancreas. Reassuringly, the measurements of beta cell fractional area and insulin replication were comparable in non-tumour-adjacent pancreas and control pancreas. Also, the frequency of TUNEL-positive beta cells was slightly (although not significantly) higher in the surgical pancreas samples than in the autopsy pancreas samples. Since TUNEL detects necrosis as well as apoptosis, these data assure that the autopsy pancreas samples studied were no more necrotic than the surgical samples. Finally, as already emphasised, we are unable to ascribe the observed tumour-adjacent islet beta cell hyperplasia in these cases to any specific growth factor, since gastrinomas express numerous growth factors. This limitation applies to prior studies showing increased islet size in pancreas of gastrinomas [18-20]. Since the factor that promotes beta cell replication adjacent to gastrinomas is unknown, it is therefore not possible to offer a mechanism through which this effect is accomplished.

In conclusion, we report islet hyperplasia and increased beta cell replication in islets adjacent to gastrinomas in human pancreas. In contrast, islet hyperplasia was not present and beta cell replication not increased in islets located $>1 \mathrm{~cm}$ from these tumours. These data suggest that islet hyperplasia in patients with Zollinger-Ellison syndrome is likely caused by the local release of gastrin and/or other growth factors from the tumour rather than by increased circulating gastrin concentrations. It might be preferable to identify which of these factors promotes beta cell replication rather than focus on the use of gastrin as a potential therapeutic agent, since at best it does not appear to promote beta cell replication in humans at concentrations that are already toxic. These studies emphasize that it is possible to drive at least a proportion of beta cells in adult humans into cell cycle. This finding supports the concept of fostering beta cell replication as a potential treatment for diabetes provided the concurrent increased beta cell apoptosis can be overcome.

Acknowledgements The excellent assistance of L. Smith and R. Basu is greatly appreciated. These studies were supported by funding from the Juvenile Diabetes Research Foundation, National Institutes of Health (DK 59579, DK61539), the Larry L. Hillblom Foundation and the Deutsche Forschungsgemeinschaft (Me 2096/2-1). We are grateful to our colleagues at the Larry Hillblom Islet Research Center, A. Bhushan, K. Maedler and T. Gurlo, for their excellent suggestions.

Duality of interest The authors declare that there is no duality of interest.

\section{References}

1. Meier JJ, Butler PC (2005) Insulin secretion. In: DeGroot LJ, Jameson JL (eds) Endocrinology, 5th edition. Elsevier Saunders, Philadelphia, pp 961-973

2. Butler AE, Janson J, Bonner-Weir S et al (2003) Beta-cell deficit and increased beta-cell apoptosis in humans with type 2 diabetes. Diabetes 52:102-110

3. Gepts W (1965) Pathologic anatomy of the pancreas in juvenile diabetes mellitus. Diabetes 14:619-633

4. Halban PA (2004) Cellular sources of new pancreatic beta cells and therapeutic implications for regenerative medicine. Nat Cell Biol 6:1021-1025

5. Robertson RP, Davis C, Larsen J, Stratta R, Sutherland DE (2000) Pancreas and islet transplantation for patients with diabetes. Diab Care 23:112-116

6. Nath DS, Gruessner AC, Kandaswamy R et al (2005) Outcomes of pancreas transplants for patients with type 2 diabetes mellitus. Clin Transplant 19:792-797 
7. Robertson RP (2004) Islet transplantation as a treatment for diabetes - a work in progress. N Engl J Med 350:694-705

8. Ryan EA, Paty BW, Senior PA et al (2005) Five-year follow-up after clinical islet transplantation. Diabetes 54:2060-2069

9. Meier JJ, Bhushan A, Butler AE, Rizza RA, Butler PC (2005) Sustained beta-cell apoptosis in patients with long-standing type 1 diabetes: indirect evidence for islet regeneration? Diabetologia 48:2221-2228

10. Rhodes CJ (2005) Type 2 diabetes - a matter of beta-cell life and death? Science 307:380-384

11. Suarez-Pinzon WL, Lakey JR, Brand SJ, Rabinovitch A (2005) Combination therapy with epidermal growth factor and gastrin induces neogenesis of human islet \{beta\}-cells from pancreatic duct cells and an increase in functional b-cell mass. J Clin Endocrinol Metab 90:3401-3409

12. Suarez-Pinzon WL, Yan Y, Power R, Brand SJ, Rabinovitch A (2005) Combination therapy with epidermal growth factor and gastrin increases beta-cell mass and reverses hyperglycemia in diabetic NOD mice. Diabetes 54:2596-2601

13. Rooman I, Lardon J, Bouwens L (2002) Gastrin stimulates beta-cell neogenesis and increases islet mass from transdifferentiated but not from normal exocrine pancreas tissue. Diabetes 51:686-690

14. Butler AE, Janson J, Soeller WC, Butler PC (2003) Increased beta-cell apoptosis prevents adaptive increase in beta-cell mass in mouse model of type 2 diabetes: evidence for role of islet amyloid formation rather than direct action of amyloid. Diabetes 52:2304-2314

15. Bonner-Weir S, Baxter LA, Schuppin GT, Smith FE (1993) A second pathway for regeneration of adult exocrine and endocrine pancreas. A possible recapitulation of embryonic development. Diabetes 42:1715-1720

16. Kendall DM, Sutherland DE, Najarian JS, Goetz FC, Robertson RP (1990) Effects of hemipancreatectomy on insulin secretion and glucose tolerance in healthy humans. N Engl J Med 322:898-903

17. Creutzfeldt W (1994) The consequences of hypergastrinemia. Yale J Biol Med 67:181-194

18. Zollinger RM, Ellison EH (1955) Primary peptic ulcerations of the jejunum associated with islet cell tumors of the pancreas. Ann Surg 142:709-723

19. Creutzfeldt W, Arnold R, Creutzfeldt C, Track NS (1975) Pathomorphologic, biochemical, and diagnostic aspects of gastrinomas (Zollinger-Ellison syndrome). Hum Pathol 6:47-76

20. Larsson LI, Ljungberg O, Sundler F et al (1973) Antor-pyloric gastrinoma associated with pancreatic nesidioblastosis and proliferation of islets. Virchows Arch A Pathol Pathol Anat 360: 305-314

21. Corleto VD, Delle Fave G, Jensen RT (2002) Molecular insights into gastrointestinal neuroendocrine tumours: importance and recent advances. Dig Liver Dis 34:668-680

22. Meier JJ, Butler AE, Galasso R, Butler PC (2006) Hyperinsulinemic hypoglycemia after gastric bypass surgery is not accompanied by islet hyperplasia or increased beta-cell turnover. Diab Care 29:1554-1559

23. Beattie GM, Montgomery AM, Lopez AD et al (2002) A novel approach to increase human islet cell mass while preserving betacell function. Diabetes 51:3435-3439

24. Lingohr MK, Dickson LM, McCuaig JF et al (2002) Activation of IRS-2-mediated signal transduction by IGF-1, but not TGF-alpha or EGF, augments pancreatic beta-cell proliferation. Diabetes 51:966-976

25. Rabinovitch A, Quigley C, Russell T, Patel Y, Mintz DH (1982) Insulin and multiplication stimulating activity (an insulin-like growth factor) stimulate islet (beta-cell replication in neonatal rat pancreatic monolayer cultures. Diabetes 31:160-164

26. Rhodes CJ (2000) IGF-I and GH post-receptor signaling mechanisms for pancreatic beta-cell replication. J Mol Endocrinol 24:303-311

27. Huotari MA, Palgi J, Otonkoski T (1998) Growth factor-mediated proliferation and differentiation of insulin-producing INS-1 and RINm5F cells: identification of betacellulin as a novel $\beta$-cell mitogen. Endocrinology 139:1494-1499

28. Movassat J, Beattie GM, Lopez AD, Portha B, Hayek A (2003) Keratinocyte growth factor and beta-cell differentiation in human fetal pancreatic endocrine precursor cells. Diabetologia 46:822-829

29. Srivastava A, Alexander J, Lomakin I, Dayal Y (2001) Immunohistochemical expression of transforming growth factor alpha and epidermal growth factor receptor in pancreatic endocrine tumors. Hum Pathol 32:1184-1189

30. Bonner-Weir S, Weir GC (2005) New sources of pancreatic betacells. Nat Biotechnol 23:857-861

31. Dor Y, Brown J, Martinez OI, Melton DA (2004) Adult pancreatic beta-cells are formed by self-duplication rather than stem-cell differentiation. Nature 429:41-46

32. Ianus A, Holz GG, Theise ND, Hussain MA (2003) In vivo derivation of glucose-competent pancreatic endocrine cells from bone marrow without evidence of cell fusion. J Clin Invest 111: $843-850$

33. Gershengorn MC, Hardikar AA, Wei C et al (2004) Epithelial-tomesenchymal transition generates proliferative human islet precursor cells. Science 306:2261-2264

34. Bonner-Weir S (2001) $\beta$-Cell turnover: its assessment and implications. Diabetes 50(Suppl 1):S20-S24

35. Meier JJ, Lin JC, Butler AE et al (2006) Direct evidence of attempted beta cell regeneration in an 89 -year-old patient with recent-onset type 1 diabetes. Diabetologia 49:1838-1844

36. Norman JT, Bohman RE, Fischmann G et al (1988) Patterns of mRNA expression during early cell growth differ in kidney epithelial cells destined to undergo compensatory hypertrophy versus regenerative hyperplasia. Proc Natl Acad Sci USA 85: 6768-6772

37. Studer H, Derwahl M (1995) Mechanisms of nonneoplastic endocrine hyperplasia - a changing concept: a review focused on the thyroid gland. Endocr Rev 16:411-426

38. Buteau J, Foisy S, Joly E, Prentki M (2003) Glucagon-like peptide 1 induces pancreatic beta-cell proliferation via transactivation of the epidermal growth factor receptor. Diabetes 52:124-132

39. Trümper A, Trümper K, Trusheim H et al (2001) Glucose-dependent insulinotropic polypeptide is a growth factor for beta (INS-1) cells by pleiotropic signaling. Mol Endocrinol 15:1559-1570

40. Drucker DJ (2003) Glucagon-like peptide-1 and the islet beta-cell: augmentation of cell proliferation and inhibition of apoptosis. Endocrinology 144:5145-5148

41. Ris F, Hammar E, Bosco D et al (2002) Impact of integrin-matrix matching and inhibition of apoptosis on the survival of purified human beta-cells in vitro. Diabetologia 45:841-850

42. Hayek A, Beattie GM, Cirulli V et al (1995) Growth factor/matrixinduced proliferation of human adult beta-cells. Diabetes 44:1458-1460

43. Ritzel RA, Butler PC (2003) Replication increases beta-cell vulnerability to human islet amyloid polypeptide-induced apoptosis. Diabetes 52:1701-1708

44. Meier JJ, Ritzel RA, Maedler K, Gurlo T, Butler PC (2005) Increased vulnerability of newly forming beta-cells to cytokineinduced cell death. Diabetologia 49:83-89 